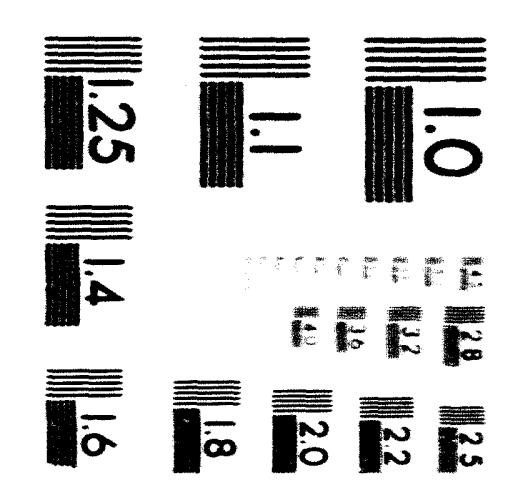



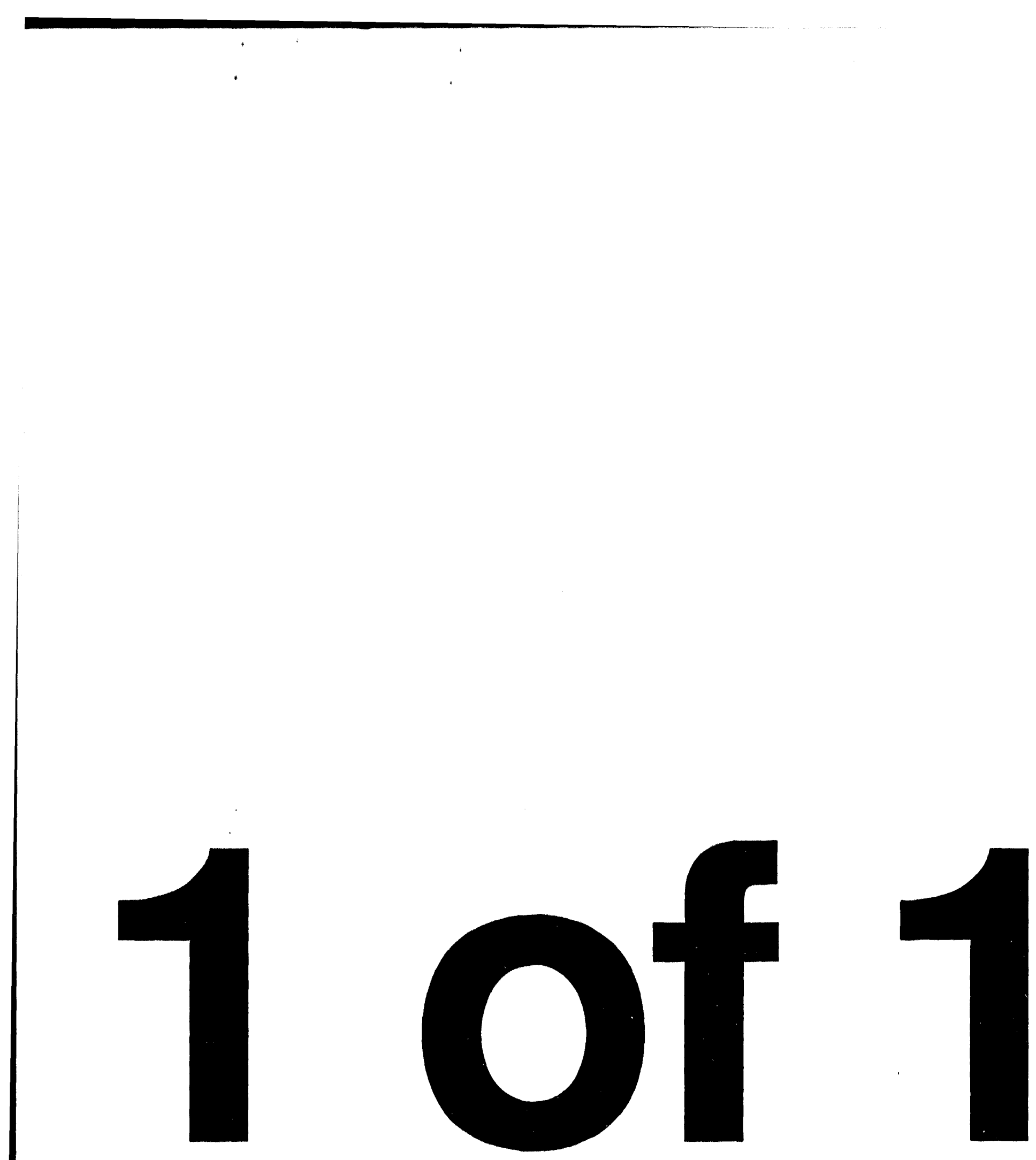


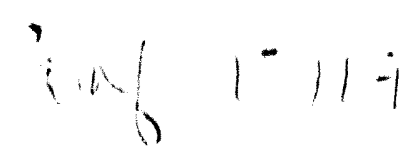

UCRL-JC-114024

PREPRINT

\title{
Immobilization in Ceramic Waste Forms of the Residues from Treatment of Mixed Wastes
}

\author{
V. M. Oversby \\ R. A. Van Konynenburg \\ W. E. Glassley \\ P. G. Curtis
}

\section{..CEIVED \\ NOV 151993 \\ O S TI}

This paper was prepared for submittal to the

Scientific Basis for Nuclear Waste Management XVII

Boston, MA

November 29 - December 3, 1993

November 1993

This is a preprint of a paper intended for publication in a journal or proceedings. Since changes may be made before publication, this preprint is made available with the understanding that it will not be cited or reproduced without the permission of the author. 


\section{DISCLAIMER}

This document was prepared as an account of wort sponsored by an agency of the United States Government. Neither the United States Government nor the Univeraity of Callfornia nor any of their employees, makes any warranty, express or implied, or assumes any lega liability or responsibility for the accuracy, completeness, or usefulness of any information, apparatus, product, or process disclosed, or represents that its use would not infringe privately owned rights. Reference herein to any specific commercial products, process, or service by trade name, trademark, manufacturer, or otherwise, does not necessarily constitute or imply its endorsement, recommendation, or favoring by the United States Govemment or the University of California. The views and opinions of authors expressed herein do not necessarily stale or reflect those of the United States Government or the University of Califomia, and shall not be used for advertising or product endorsement purposes. 


\title{
IMMOBILIZATION IN CERAMIC WASTE FORMS OF THE RESIDUES FROM TREATMENT OF MIXED WASTES
}

\author{
V. M. OVERSBY, R. A. VAN KONYNENBURG, W. E. GLASSLEY, and P. G. CURTIS
} Lawrence Livermore National Lab, Livermore, CA, 94550.

\section{ABSTRACT}

The Environmental Restoration and Waste Management Applied Technology Program at LLNL is developing a Mixed Waste Management Facility to demonstrate treatment technologies that provide an alternative to incineration. As part of that program, we are developing final waste forms using ceramic processing methods for the immobilization of the treatment process residues. The ceramic phase assemblages are based on using Synroc D as a starting point and varying the phase assemblage to accommodate the differences in chemistry between the treatment process residues and the defense waste for which Synroc D was developed. Two basic formulations are used, one for low ash residues resulting from treatment of organic materials contaminated with RCRA metals, and one for high ash residues generated from the treatment of plastics and paper products. Treatment process residues are mixed with ceramic precursor materials, dried, calcined, formed into pellets at room temperature, and sintered at 1150 to $1200^{\circ} \mathrm{C}$ to produce the final waste form. This paper discusses the chemical composition of the waste streams and waste forms, the phase assemblages that serve as hosts for inorganic waste elements, and the changes in waste form characteristics as a function of variation in process parameters.

\section{INTRODUCTION}

In the early 1980's LLNL developed a ceramic waste form based on titanate and zirconate minerals for the immobilization of the reprocessing residues held at Savannah River [1]. That waste form, Synroc-D, is presently being used as the basis for design and demonstration of a ceramic waste form for the immobilization of the residues resulting from the treatment of DOE hazardous and mixed wastes.

The Environmental Restoration and Vaste Management Applied Technology Program at LLNL is developing a Mixed Waste Management Facility (MWMF) to demonstrate a variety of technologies that can be used as alternatives to incineration in the treatment of mixed wastes. The waste streams that will form the core of the demonstration project are DOE 
waste codes 2110 (7.8\% Trimsol in water), 2120 (Aqueous/nonhalogenated organic), 2210 (T'richloroethane), 5300 (Combustible), 5440 (Predominantly combustible), and 6100 (Lab packs- Scintillation cocktails). The residues from treatment of the Combustible waste streams $(5300$ and 5440 ) result in about 10 percent of the original weight of waste being recovered as ash. The ash composition for the LLNL combustible stream is dominated by $\mathrm{SiO}_{2}, \mathrm{Al}_{2} \mathrm{O}_{3}, \mathrm{MgO}, \mathrm{ZnO}, \mathrm{CaO}$, and $\mathrm{Fe}_{2} \mathrm{O}_{3}$, which collectively account for almost $90 \%$ of the ash. In contrast, the other waste streams result in a concentrated residue with very little of the major mineralforming oxides found in the combustible ash; the low ash residues are dominated by $\mathrm{Sb}, \mathrm{Zn}$, and $\mathrm{Ba}$, with lesser amounts of $\mathrm{B} \%, \mathrm{Mo}, \mathrm{Pb}$, and $\mathrm{U}$. Other metals (Co, Cd, $\mathrm{Ni}, \mathrm{Cu}, \mathrm{Mn}, \mathrm{Ag}, \mathrm{V}, \mathrm{Tl}$, and $\mathrm{Cr}$ ) will be present in trace amounts. These elements, recovered as nitrate salts or as oxides after the destruction of the organic liquid waste streams, are also found in small amounts in the ash residues from processing of the two combustible waste streams.

\section{DESIGNING THE WASTE FORM}

Our philosophy in designing a ceramic waste form for the waste treatment residues was to use the ash components from the combustible waste streams as the model for our base ceramic compositions, adding to that ash small amounts of additive ciremicals to produce a final phase assemblage that had proven durability and known processing parameters. Addition of $\mathrm{NaOH}, \mathrm{ZrO}_{2}$, and $\mathrm{TiO}_{2}$ to the combustible ash provides a phase assemblage similar to that found in Synroc D.

The major phases in Synroc-D are nepheline, perovskite, spinel, and zirconolite. For Savannah River wastes, which are high in iron, there were 2 spinels $-\mathrm{Fe}_{2} \mathrm{TiO}_{4}$ and $\mathrm{FeAl}_{2} \mathrm{O}_{4}$; however, the common natural spinel has the composition $\mathrm{MgAl}_{2} \mathrm{O}_{4}$ and is capable of extensive solid solution. For immobilization of residues from treatment of hazardous and mixed wastes we are using the phase assemblage of nepheline, perovskite, zirconolite, and $\mathrm{MgAl}$-spinel as the major phases. The toxic metals and radioactive elements in the treatment residues will be incorporated into the waste form as solid solutions in the major phases. In some cases, elements such as $\mathrm{Hg}$ and $\mathrm{Ag}$ (as $\mathrm{AgCl}$ ) will be volatile under the conditions used to make the ceramic waste form. These elements will be condensed from the offgas line and converted into a suitable secondary waste form.

The process we are using for producing the final ceramic product differs substantially from the original flow sheet for Synroc-D processing. We are planning to use a rotary calciner operating at 600 to $750^{\circ} \mathrm{C}$ to calcine and denitrate the ceramic waste form feed stream and induce 
formation of the primary bonds in the ceramic. This is the process used for Synroc-C processing at the Australian Nuclear Science and Technology Organisation, rather than the fluidized bed calciner ultimately employed at LLNL for work on Synroc D [2]. Following calcination, the powder will be pressed at room temperature into 1-cm-diameter pellets using a high capacity, commercially available, pellet press. The pressed pellets will be sintered in air or in a controlled atmosphere at approximately $1200^{\circ} \mathrm{C}$ to densify the pellets and produce the desired phase assemblages.

\section{WASTE FORM COMPOSITION AND CHARACTERISTICS}

We have chosen two basic compositions for the waste forms we are using to develop process parameters and waste form characteristics for the treatment process residues. The first waste form represents the pure endmember composition for low ash residues and is illustrated in Table 1. Rather than use the expected concentrations of waste elements, which are high in $\mathrm{Sb}, \mathrm{Zn}$, and $\mathrm{Ba}$, we have chosen to use equal amounts of 10 elements at approximately $0.5 \%$ each so that we have enough present in

Table 1: Compositions of ceramic mixtures using oxide starting materials used to simulate residues from treatment of low-ash streams and to investigate volatility of waste elements. Waste oxides are equal weight percents of oxides of $\mathrm{Co}, \mathrm{Cu}, \mathrm{Sb}, \mathrm{Cr}, \mathrm{Zn}, \mathrm{Mo}, \mathrm{Ag}, \mathrm{Cd}, \mathrm{Ba}$, and $\mathrm{Pb}$.

Component Weight $\% \quad$ Mineral in which component is found

$\mathrm{CaO}$

$\mathrm{TiO}_{2}$

$\mathrm{ZrO}_{2}$

$\mathrm{MgO}$

$\mathrm{Al}_{2} \mathrm{O}_{3}$

$\mathrm{SiO}_{2}$

$\mathrm{Na}_{2} \mathrm{O}$

Waste Oxides

Mineral Phase Weight \%

Perovskite

Zirconolite

Spinel

Nepheline

Rutile
16.1

29.9

10.8

6.8

22.0

5.7

3.0

5.7

29.5

31.2

25.1

14.2

0
Perovskite, Zirconolite

Perovskite, Zirconolite, Rutile

Zirconolite

Spinel

Spinel, Nepheline

Nepheline

Nepheline

Various

Composition of end member phase

$\mathrm{CaTiO}_{3}$

$\mathrm{CaZrTi}_{2} \mathrm{O}_{7}$

$\mathrm{MgAi}_{2} \mathrm{O}_{4}$

$\mathrm{NaAlSiO}_{4}$

$\mathrm{TiO}_{2}$ 
the waste form to easily characterize the product. We have prepared samples of this synthetic waste form using oxide materials (gibbsite and kaolin for $\mathrm{Al}$ and $\mathrm{Si}$ oxides) as well as alkoxide preparations. For the alkoxide and one batch of oxide material we have also used $1.6 \% \mathrm{NaCl}$ in the mixture to investigate the effects of the presence of chloride ions on the behavior of the waste elements and to determine whether sodalite could be formed as part of the phase assemblage.

For each mixture we have prepared samples by mixing the oxides or alkoxide precursors with the waste element oxides using water to facilitate mixing. The mixture is then dried in air at $90^{\circ} \mathrm{C}$ to remove the bulk of the water, calcined at $600^{\circ} \mathrm{C}$ for periods between 1 and 8 hours, and cooled to room temperature. The powder is then mixed with Carbowax to act as a binder and pressed into pellets at 25,000 psi in tool steel dies. The pressed pellets are sintered for 1 hour at temperatures between 1050 and $1250^{\circ} \mathrm{C}$. The green density of pellets prepared using oxide starting materials and the binder material is generally about 52 to $57 \%$ of the theoretical maximum density of the sintered product.

Figure 1 shows the density of samples as a function of sintering temperature. The five data sets marked Oxide $+\mathrm{NaCl}$, Oxide, no $\mathrm{NaCl}$, and Alkoxide $+\mathrm{NaCl}$ all had approximately the composition shown in Table 1 . For pellets made using oxide starting materials, sintering at $1050^{\circ} \mathrm{C}$ drives off the Carbowax, but does not appreciably densify the pellet; thus, the sintered density is a little less than the green density. Sintering at temperatures between 1100 and $1200^{\circ} \mathrm{C}$ produces an increase in density that is approximately linear with temperature. Samples sintered at $1200^{\circ} \mathrm{C}$ achieve about $90 \%$ of theoretical density. Differential thermal analysis of our samples has shown that the solidus is at about $1180^{\circ} \mathrm{C}$, so these samples experience some melting. Scanning electron microscopy and transmission electron microscopy do not reveal any significant evidence of melting, so it must have been confined to grain boundaries. Sintering an oxide mixture at $1250^{\circ} \mathrm{C}$ produced a sample with $97 \%$ of theoretical density and obvious signs of melting.

Samples produced from alkoxide precursors with the compositions given in Table 1 also had green densities of 52 to $55 \%$, but showed considerable densification upon sintering at $1050^{\circ} \mathrm{C}$, indicating that the alkoxide materials are more reactive than the oxide equivalents. Somewhat surprisingly, these samples did not reach more than $80 \%$ of theoretical density when sintered at higher temperatures. It has been suggested [3] that this may be due to the high surface area of the alkoxide powders and the adsorption of gases on the powders after calcination. These gases may then be trapped in the pellets after pressing and cause 
porosity in the sintered pellet. Alternatively, the nitrates added with waste elements may not have completely decomposed during calcination.

Table 2 shows the composition of a simulated waste form designed to represent the high ash residues obtained by processing a mixture of combustible solids such as plastics, rubber, and paper products. We used the average of a one-year inventory of such wastes at LLNL to generate the composition of the waste stream. In the waste form composition given, all of the $\mathrm{Si}$ and $\mathrm{Mg}$ come from the waste stream residues, as well as $1 / 4$ of the Al and most of the Ca. The waste loading in the simulated waste form is about $50 \%$ and the waste stream is low in components such as $\mathrm{Sb}$ and $\mathrm{Ba}$ that are high in the low ash residues. The simulated waste form for the composition in Table 2 has a different proportion of phases than the low ash host, notably being high in both nepheline and spinel, and with little perovskite. (The apatite is assumed to be present because of the phosphate content; it has not yet been positively identified and the phosphate may be in another phase). Despite the gross difference in phase proportions and in bulk composition of the two phase assemblages, the processing characteristics for both are similar and the SEM images and energy dispersive $x$-ray characterization of both indicate that they are similar. Because of these similarities, we anticipate that it will be possible to combine the residues from the low ash stream with the high ash residues from treatment of combustible solids and produce a single waste form for both streams.

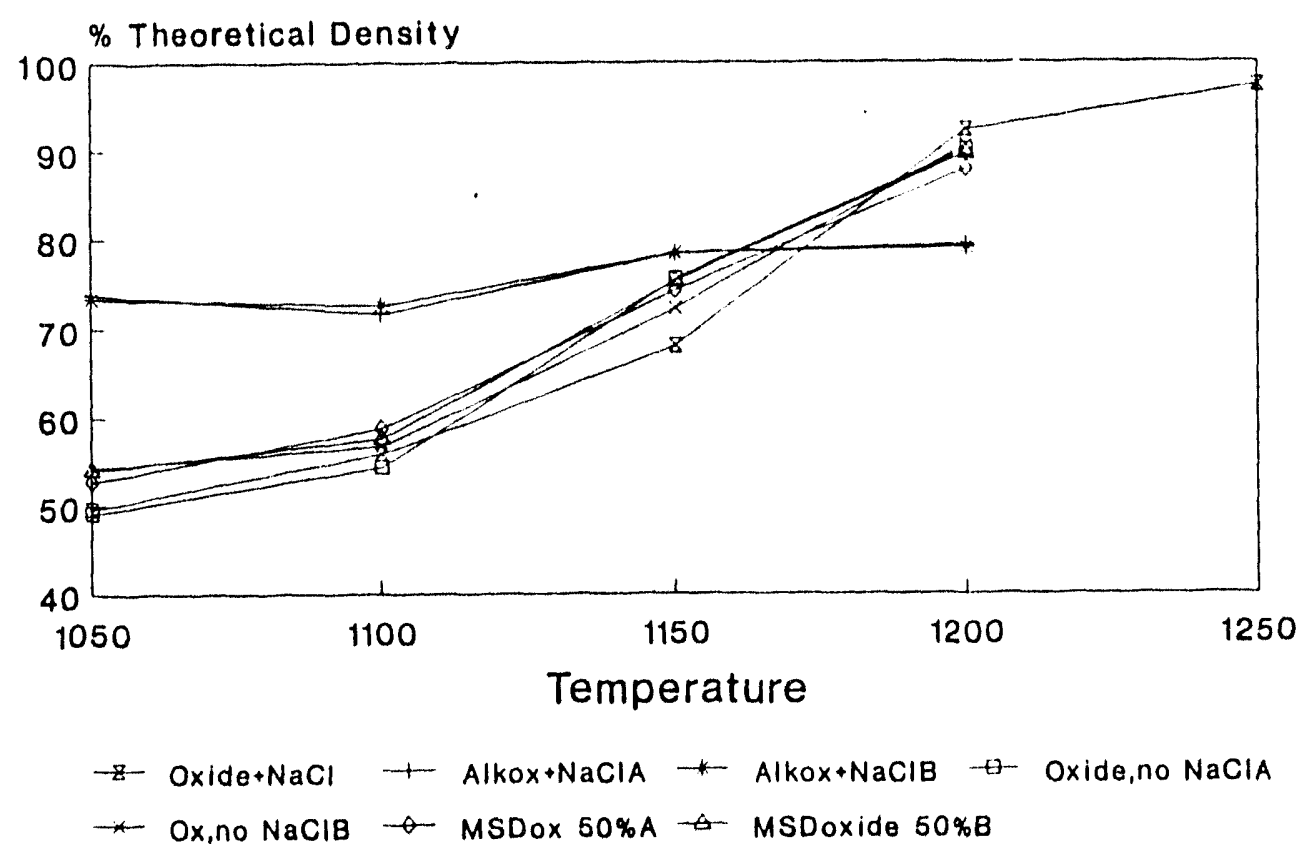

Fig. 1 Density of waste form pellets as a function of sintering temperature. Samples marked A and B are duplicate pellets separately processed. 
Table 2: Compositions of ceramic mixtures using oxide starting materials to simulate residues from processing of combustible materials through the Molten Salt process (MSD ox $50 \%$ in Fig. 1). Waste oxides are $0.1 \%$ of oxides of $\mathrm{Cu}, \mathrm{Sr}, \mathrm{Cr}, \mathrm{Ce}, \mathrm{Mo}, \mathrm{Mn}, \mathrm{Ni}$, and $\mathrm{V}, 0.05 \% \mathrm{PbO}, 0.15 \% \mathrm{BaO}, 0.2 \%$ each of oxides of $\mathrm{B}$ and $\mathrm{Sb}$, and $0.6 \%$ sodium sulfate.

\section{Component Weight $\% \quad$ Mineral containing component}

$\begin{array}{lcl}\mathrm{CaO} & 4.4 & \text { Perovskite, Zirconolite, Apatite } \\ \mathrm{TiO}_{2} & 8.9 & \text { Perovskite, Zirconolite, Rutile } \\ \mathrm{ZrO}_{2} & 3.9 & \text { Zirconolite } \\ \mathrm{MgO} & 7.4 & \text { Spinel } \\ \mathrm{Al}_{2} \mathrm{O}_{3} & 40.2 & \text { Spinel, Nepheline } \\ \mathrm{SiO}_{2} & 16.8 & \text { Nepheline } \\ \mathrm{Na}_{2} \mathrm{O} & 7.9 & \text { Nepheline } \\ \mathrm{K}_{2} \mathrm{O} \text { (waste only) } & 1.0 & \text { Nepheline } \\ \mathrm{Fe}_{2} \mathrm{O}_{3} \text { (waste only } & 1.6 & \text { Spinel } \\ \mathrm{ZnO}_{\text {(waste only) }} & 3.7 & \text { Spinel } \\ \mathrm{P}_{2} \mathrm{O}_{5} \text { (waste only) } & 2.2 & \text { Apatite (with } \mathrm{Ca}, \mathrm{Ce}, \mathrm{Sr}, \mathrm{Ba} \text { ) } \\ \text { Waste Oxides } & 2.0 & \text { Various }\end{array}$

Mineral Phase

Perovskite, Rutile,

Apatite,

Zirconolite

Spinel

Nepheline
Weight $\%$

9

11

40

40
Model Composition

$\mathrm{CaTiO}_{3}, \mathrm{TiO}_{2}, \mathrm{Ca} 5\left(\mathrm{PO}_{4}\right)_{3}(\mathrm{OH}, \mathrm{Cl}, \mathrm{F})$

$\mathrm{CaZrTi}_{2} \mathrm{O}_{7}$

$\mathrm{MgAl}_{2} \mathrm{O}_{4}$

$\mathrm{NaAlSiO}_{4}$

\section{CHARACTERIZATION OF SINTERED WASTE FORMS}

Each sintered sample is weighed and measured to determine density; $x$-ray diffraction and fluorescence are also done. Selected samples are then examined by scanning electron microscope. Samples sintered at $1200^{\circ} \mathrm{C}$, with $90 \%$ of theoretical density, show porosity distributions that indicate the formation of gas bubbles inside the sample during sintering. Thus, the porosity is largely not interconnected and should not greatly affect the leaching characteristics of the waste form pellets. The SEM micrographs show that the grain size of the sintered pellets remains small - less than 1 micrometer on average - even at the highest sintering temperatures. Increasing the sintering time from 1 hour to 10 hours did not produce noticeable additional grain growth. The very fine grain size makes identification of the mineral phases and characterization using SEM energy dispersive $x$-ray analysis (EDX) very difficult. Despite the fine 
grain size, we have been able to obtain a number of EDX spectra that show nearly pure phase compositions for each of the major mineral phases.

The sample sintered at $1250^{\circ} \mathrm{C}$ was examined by SEM and EDX to determine the distribution of waste elements within the major mineral phases. For elements where clear identification was possible, the host phases are listed in Table 3.

Because the waste streams that will be treated in the MWMF will not be uniform ir chemical composition, and because other mixed waste streams may eventually be treated in the MWMF, we are interested in identifying which chemical elements may affect the processing characteristics and final quality of the waste form. Chloride is the first element that we have examined, because it will be present in the residues from treatment of chlorinated hydrocarbon wastes and is readily soluble as $\mathrm{NaCl}$. Addition of $\mathrm{NaCl}$ to the oxide and alkoxide mixtures with compositions given in Table 1 did not adversly affect the densification of the waste form at a given sintering temperature. Examination by $\mathrm{x}$-ray fluorescence analysis using pellets formed from uncalcined powders as control samples showed that pellets formed from calcined powders were indistinguishable in composition from the control samples. Sintering at $1050^{\circ} \mathrm{C}$ caused most of the $\mathrm{Ag}$ in the samples to be lost, presumably because of the volatility of $\mathrm{AgCl}$ (vapor pressure of $6.6 \mathrm{~mm} \mathrm{Hg}$ at $1050^{\circ} \mathrm{C}$ using the data given in [4]). For samples sintered at $1200^{\circ} \mathrm{C}$ in the presence of $\mathrm{Cl}$, all $\mathrm{Ag}$ was gone. Ion microprobe analysis of these samples gave some indications that $\mathrm{Pb}$ and $\mathrm{Sb}$ might also be partially lost in the presence of $\mathrm{Cl}$ at the highest sintering temperatures.

Mixtures having the composition given in Table 1, but without $\mathrm{NaCl}$ intentionally added also showed loss of $\mathrm{Ag}$ at $1050^{\circ} \mathrm{C}$; however, no further loss occurred at higher sintering temperatures. Silver oxide decomposes at

Table 3: Distribution of waste elements in major phases for the mixture given in Table 1. Sample sintered at $1250^{\circ} \mathrm{C}$. Partial melting occurred.

Waste Element Host phases

Molybdenum

Antimony

Cadmium

Copper

Zinc

Cobalt

Chromium
AlSiCa phase (unidentified)

Zirconolite and perovskite

Zirconolite and perovskite

Spinel, (nepheline/glass ?)

Spinel, (nepheline/glass ?)

Spinel

Spinel 
temperatures above about $1600 \mathrm{C}|5|$. Since the vapor pressure of $\mathrm{Ag}$ metal at $1050^{\circ} \mathrm{C}$ is very low 141 , we presume that trace $\mathrm{Cl}$ impurities in the materials used to make the simulated waste forms have combined with the $\mathrm{Ag}$ released on $\mathrm{Ag}_{2} \mathrm{O}$ decomposition and later volatilized. Chloride could not be excluded in any practical waste treatment operation, so provisions for collection of $\mathrm{Ag}$ from off-gases will need to be included in the waste form fabrication area for any processes operating at temperatures above about 900 to $1000^{\circ} \mathrm{C}$.

\section{CONCLUSIONS}

We have designed a ceramic waste form based on the phases nepheline, zirconolite, perovskite, and spinel to use for immobilization of the residues from treatment of organic mixed waste. The waste form is similar in composition and processing parameters to SYNROC D, so would also be suitable for immobilization of sludges. Chloride has been shown to cause $\mathrm{Ag}$ to be lost during processing at temperatures of $1050^{\circ} \mathrm{C}$, and may also enhance volatility of $\mathrm{Pb}$ and $\mathrm{Sb}$.

\section{ACKNOWLEDGEMENTS}

We thank Jim Yoshiyama and Bill Beiriger for SEM, XRD, and XRF analyses of the samples prepared as part of this study. Work performed under the auspices of the US Department of Energy by the Lawrence Livermore National Laboratory under Contract number W-7405-ENG-48.

\section{REFERENCES}

1. J. H. Campbell, C. L. Hoenig, F. J. Ackerman, P. E. Peters, and J. Z. Grens, Incorporationn of high-level wastes in Synroc: Results from recent process engineering studies at Lawrence Livermore National Laboratory, in Mat. Res. Soc. Symp. Proc. Vol. 11, W. Lutze, ed., pp. 299308 (1982).

2. A. E. Ringwood, S. E. Kesson, K. D. Reeve, D. M. Levens, and E. J. Ramm, SYNROC, in Radioactive waste forms for the future, edited by W. Lutze and R. C. Ewing (Elsevier Science Publishers B. V. , New York, 1988), p. $233-334$.

3. A. Jostsons and E. Vance, ANSTO, personal communication.

4. Smithells Metal Reference Book. 6th ed., edited by E. A. Brandes, (Butterworths), 1983.

5. F. A.Cotton and G. Wilkinson, Advanced Inorganic Chemistry, Interscience Publishers, 1962. 
